\title{
PENGARUH MODEL PEMBELAJARAN PEMECAHAN MASALAH TERHADAP MOTIVASI BERPRESTASI DAN PRESTASI BELAJAR IPS SISWA KELAS VIII MTS. MU'ALLIMAT NW PANCOR
}

\author{
${ }^{1}$ RR. Sri Setyawati Mulianingsih, ${ }^{2}$ Zidni \\ 1,2 Universitas Hamzanwadi \\ setyawati.mulyaningsih@pasca.undikha.ac.id, nizidni@gmail.com
}

\begin{abstract}
Abstrak
Penelitian ini bertujuan untuk mengetahui pengaruh penggunaan model pembelajaran Pemecahan masalah terhadap motivasi berprestasi dan prestasi belajar IPS. Penelitian ini dilaksanakan di MTs. Mu'allimat NW Pancor dengan menguunakan post-test control group design, yang hanya memperhitungkan skor post test. Variabel bebas dalam penelitian ini adalah penggunaan model pembelajaran Pemecahan masalah dan variabel terikatnya adalah motivasi berprestasi dan prestasi belajar IPS. Instrumen berupa kuisioner motivasi berprestasi dan prestasi belajar IPS. Sampel Penelitian berjumlah 30 sebagai kelompok eksperimen dan 30 sebagai kelompok kontrol yang diambil secara acak. Data yang diperoleh dari kuisioner dan tes tersebut selanjutnya ditabulasi menjadi dua kelompok, yaitu kelompok peserta didik yang mengikuti pelajaran IPS dengan menggunakan model pembelajaran Pemecahan masalah (kelompok eksperimen) dan kelompok peserta didik yang mengikuti pelajaran IPS tanpa menggunakan konvenional (kelompok kontrol). Setelah uji asumsi analisis ini terpenuhi barulah pengujian dilakukan dengan menggunakan Uji Manova. Hasil analisis pada penelitian menunjukkan bahwa: hasil belajar kelompok peserta didik yang mengikuti pelajaran IPS dengan menggunakan model pembelajaran Pemecahan masalah (kelompok eksperimen) lebih tinggi dibandingkan dengan kelompok peserta didik yang mengikuti pelajaran IPS yang menggunakan konvensional atau tanpa model pembelajalaran Pemecahan masalah. Oleh karena itu dapat disimpulkan bahwa penggunaan model pembelajarlan Pemecahan masalah memiliki pengaruh yang cukup besar terhadap motivasi berprestasi dan prestasi belajar IPS pada siswa kelas VIII MTs Mu'allimat NW Pancor.
\end{abstract}

Kata Kunci: Model Pemebelajaran Pemecahan Masalah, Motivasi Berprestasi, Prestasi Belajar IPS.

\section{PENDAHULUAN}

Secara umum kondisi pembelajaran IPS dewasa ini ditengarai bahwa pola pembelajaran yang dikembangkan oleh guru cenderung bersifat guru sentris sehingga peserta didik hanya menjadi obyek pembelajaran (Bunyamin, 2006). 
Model pembelajaran yang demikian itu, cenderung berangkat dari asumsi dasar bahwa pembelajaran IPS hanya dimaksudkan sekadar mentrasfer pengetahuan atau konsep dari kepala guru ke kepala siswa. Akibatnya, guru telah merasa membelajarkan namun siswa belum belajar. Konsekwensi logis dari pola pembelajaran yang demikian pada dasarnya sudah menyalahi kodrat terhadap tujuan dan peran kritis yang diemban oleh IPS. Hal itu merupakan hulu dan hilir dari pembelajaran IPS.

Sebagai akibatnya, dalam kenyataan sering dijumpai bahwa pembelajaran Ilmu Pengetahuan Sosial disajikan tidak menarik, malah terkesan membosankan sehingga kurang merangsang siswa untuk berpikir kritis dan kurang memiliki kemampuan memecahkan permasalahan. Padahal, kemampuan berpikir kritis dan kemampuan mengatasi masalah merupakan kompetensi yang harus dimiliki oleh siswa. Diungkapkan Hamalik (2008: 152) bahwa peserta didik harus dilatih tentang cara memecahkan masalah dengan mengembangkan kemampuan berpikir yang terarah untuk menghasilkan gagasan mengenai berbagai macam pemecahan masalah dalam upaya mencapai tujuan.

Kemampuan memecahkan masalah, di samping sebagai hasil belajar juga merupakan bekal bagi mereka untuk mengatasi permasalahan kehidupan yang selalu melingkupi kehidupannya. Berbagai masalah tersebut hendaknya dimaknai secara positif karena dengan adanya masalah, orang akan mencoba melakukan pemecahan masalah untuk mengatasi masalah yang dihadapinya atau bisa jadi orang mengatasi masalah untuk mencapai kemajuan. Sukmadinata (2004: 241) mengemukakan, kemajuan sesungguhnya dicapai karena keberhasilan orang memecahkan masalah yang dihadapinya. Hampir semua kemajuan, pembaharuan,temuan dan inovasi berawal dari adanya masalah, hambatan, kesulitan, ancaman orang, kelompok atau bangsa yang maju adalah yang mampu mengatasi dan memecahkan masalah.

Kegiatan pembelajaran IPS di sekolah menunjukkan ciri-ciri yaitu: (1) Pola pembelajaran IPS yang lebih mementingkan hasil dari pada proses sehingga belajar menjadi tidak bermakna bagi siswa. Akibatnya siswa menjadi kesulitan menyelesikan masalah dalam konteks yang lebih luas dan dalam konteks kehidupan sehari-hari. (2) Interaksi yang terjadi dalam pembelajaran masih didominasi guru atau interaksi satu arah. Hal ini cenderung menyebabkan siswa bersifaf pasif, mereka lebih banyak menunggu sajian guru. Mereka menjadi kurang tertarik untuk menemukan sendiri pengetahuan tersebut. Bruner, mengatakan bahwa berusaha sendiri untuk mencari pemecahan masalah serta pengetahuan yang menyertainya, menghasilkan pengetahuan 
Pengaruh Model ....- RR. Sri Setyawati M. dan Zidni

yang benar-benar bermakna. (3) Pembelajaran lebih banyak berorientasi pada tercapainya penguasaan materi, yang terbukti berhasil dalam jangka pendek. Namun demikian, dalam jangka panjang, pembelajaran tersebut gagal membekali anak anak dalam memecahkan masalah. (4) Guru dalam proses pembelajaran belum banyak mengembangkan kemampunan berpikir divergen. Guru dalam memberikan permasalahan kepada siswa, masih berorientasi pada masalah yang hanya memuat satu jawaban yang benar, belum mengkaji permasalahan sampai pada titik kulminasi refleksi.

Salah satu alternatif yang diduga mampu menjembatani persoalan tersebut adalah dengan melakukan inovasi pada model pengorganisasian materi, model pembelajaran, buku ajar, dan perangkat penilaian IPS. Guru IPS harus memiliki kemampuan untuk merancang dan melaksanakan program pembelajaran secara terpadu yang harus diintegrasikan dengan baik, dan secara terus-menerus menyegarkan, memperluas, dan memperdalam pengetahuan tentang ilmu-ilmu sosial dan nilai-nilai kemanusiaan untuk menuju ke arah itu. Hendaknya guru IPS memahami, melaksanakan, dan memegang teguh tentang landasan-landasan pendidikan IPS, yang terdiri dari: "landasan filosofis, ideologis, sosiologis, antropologi, kemanusiaan, politik, psikologi, dan landasa religius" (Sapria, 2009). Namun allternatif tindakan untuk meningkatkan kualitas pembelajaran IPS dengan mendorong keterlibatan siswa untuk aktif dalam kegiatan pembelajaran serta meningkatkan keterampilan guru dan meningkatkan prestasi siswa menggunakan model pemecahan masalah. Proses pemecahan masalah memberikan kesempatan kepada siswa terlibat secara aktif dalam mempelajari, mencari, menemukan sendiri informasi untuk diolah menjadi konsep, prinsip, teori, atau kesimpulan. Model pemecahan masalah merupakan kemampuan memproses informasi untuk membuat keputusan dalam memecahkan masalah.

Tujuan umum dalam penelitian ini adalah untuk mengetahui pengaruh penggunaan model pembelajaran pemecahan masalah terhadap motivasi dan prestasi IPS siswa kelas VIII MTs. Mu'allimat NW Pancor. Tujuan khusus dalam penelitian ini (1) Untuk mengetahui perbedaan motivasi berprestasi antara kelompok siswa yang mengikuti pembelajaran model pemecahan masalah dengan kelompok siswa yang mengikuti pembelajar konvensional. (2) Untuk mengetahui perbedaan prestasi belajar IPS antara kelompok siswa yang mengikuti pembelajaran model pemecahan masalahl dengan kelompok siswa yang mengikuti pembelajaran konvensional. (3) Untuk mengetahui perbedaan motivasi berprestasi dan prestasi belajar IPS secara bersama- 
Pengaruh Model ....- RR. Sri Setyawati M. dan Zidni

sama antara kelompok siswa yang mengikuti pembelajaran pemecahan masalah dengan siswa yang mengikuti pembelajaran konvensional konvensional.

Pengajaran berdasarkan pemecahan masalah telah dikenal sejak zaman John Dewey. Menurut Dewey (dalam Sudjana, 2001: 19), belajar berdasarkan masalah adalah interaksi antara stimulus dengan respons, merupakan hubungan atara dua arah. Belajar dan lingkungan memberi masukan kepada siswa karena bantuan dan masalah. Selanjutnya, Sumiati (2009: 138-139) mengatakan bahwa pemecahan masalah merupakan suatu proses untuk menemukan suatu masalah yang dihadapi berupa aturanaturan baru yang tarafnya lebih tinggi. Menurut Fisher (1987: 2) pemecahan masalah adalah suatu proses dimana anak dapat belajar untuk menggunakan pengetahuan mereka berdasarkan konsep dan keterampilan-keterampilan yang ada pada diri anak. Keterampilan-keterampilan yang harus dimiliki adalah kritis, kreatif, dan strategis seperti mengamati, perancangan, pengambilkan keputusan, kerjasama kelompok, pengungkapan pendapat, menerapkan dan mengevaluasi solusi dan seterusnya.

Menurut Arends (dalam Trianto, 2007: 68) "it is strange that we expect studens to solve problems yet seldom teach then problem about solving", yang berarti dalam mengajar guru selalu menuntut siswa untuk belajar dan jarang memberikan pelajaran tentang bagaimana siswa untuk belajar, guru juga menuntut siswa untuk menyelesaikan masalah, tetapi jarang mengajarkan bagaimana siswa seharusnya menyelesaikan masalah. Permasalahannya sekarang adalah bagaimana menemukan cara yang terbaik untuk menyampaikan berbagai konsep yang diajarkan, sehingga siswa dapat menggunakan dan mengingat lebih lama konsep tersebut. Bagaimana guru dapat berkomunikasi dengan baik dengan siswanya. Bagaimana guru dapat membuka wawasan berpikir yang beragam dari seluruh siswa, sehingga dapat mempelajari berbagai konsep dan cara mengaitkannya dalam kehidupan nyata. Bagaimana sebagai guru yangt baik dan bijaksana mampu menggunakan model pembelajaran yang berkiaitan dengan cara pemecahan maslah.

Beberapa definisi di atas dapat disimpulkan bahwa model pemecahan masalah adalah cara penyajian bahan pelajaran dengan menjadikan masalah sebagai titik tolak pembahasan untuk dianalisis dan disintesis dalam usaha mencari pemecahan masalah atau jawabannya oleh siswa. Jadi model ini memberikan tekanan pada terselesaikannya suatu masalah secara menalar.

Menurut KBB I kata motivasi berarti dorongan yang timbul pada diri seseorang secara sadar atau tidak sadar untuk melakukan suatu tindakan dengan tujuan tertentu. 
Motivasi merupakan suatu istilah yang aklan menghasilkan kegigihan perilaku yang diarahkan untuk mencapai tujuan. Menurut Morgan (dalam Sukadji, 1993) motivasi dan motif sering dipakai dengan pengertian yang sama. Menurut Santrock (2007) motivasi adalah proses yang memberi semangat, arah dan kegigihan, perilaku. David C. M. McClelland, dkk., mengemukakan bahwa manusia dalam berinteraksi dengan lingkungannya seringkali dipengaruhi oleh berbagai motif. Motif tersebut berkaitan dengan keberadaan dirinya sebagai makhluk biologis dan makhluk sosial yang selalu berhubungan dengan lingkungan. Motivasi yang dikemukakan oleh McClelland salah satunya yaitu di antaranya, yaitu motivasi untuk prestasi. Thantawi (1997: 7) mengatakan motivasi merupakan variabel yang berpengaruh yang biasanya menjelaskan faktor dalam organisme yang menimbulkan, menjaga mengarahkan tingkah laku mencapai tujuan.

Beberapa pengertian di atas dapat ditarik kesimpulan bahwa motivasi merupakan suatu istilah umum yang dapat digunakan keseluruhan jenis dorongan, keinginan, kebutuhan harapan dan sebagainya. Selain itu, motivasi juga dimaknai sebagai proses yang melibatkan proses dimana energi, langsung, dan tingkah laku didorong atau suatu hal yang mendorong mendorong seseorang untuk melakukan sesuatu atau mendapatkan sesuatu.

Prestasi belajar adalah hasil yang dicapai oleh seseorang setelah ia melakukan perubahan belajar, baik di sekolah maupun di luar sekolah. "Achievement test a standardized test for measuring the skill or knowledge by person in one more lines of work a study" (Webster's New International Dictionary, 1951: 20). Djamarah (1994) mendefinisikan prestasi belajar sebagai hasil dari aktivitas dalam belajar. Kalau perubahan tingkah laku adalah tujuan yang mau dicapai dari aktivitas belajar, maka perubahan tingkah laku itulahsalah satu indikator yang dijadikan pedoman untuk mengetahui kemajuan individu dalam hal yang diperolehnya di sekolah. Dengan kata lain prestasi belajar merupakan kemampuan-kemampuan yang dimiliki oleh siswa sebagai akibat perbuatan belajar atau setelah menerima penglaman belajar, yang dapat dikategori kanmenjadi tiga ranah, yakni ranah kognitif, afektif, dan psikomotor.

Faktor-faktor yang dapat mempengaruhi prestasi belajar antara lain: (1) faktor individual, seperti: kematangan/pertumbuhan, kecerdasan, latihan, motivasi dan faktor pribadi, (2) faktor sosial, seperti: faktor keluarga/kondisi rumah tangga, guru dan cara mengajarnya, lingkungan dan kesempatan yang tersedia dan motivasi sosial (Purwanto, 1990: 102). Sedangkan menurut bahwa faktor-faktor yang mempengaruhi belajar 
banyak jenisnya, tetyapi secara garis besar dapat digolomngkan menjadi dua golongan saja, yaitu faktor intern dan faktor ekstern. Faktor intern diklasifikasikan menjadi tiga faktor, yaitu; faktor jasmaniah, faktor psikologis dan faktor kelelahan, Faktor jasmaniah antara lain: kesehatan, dn cacat tubuh. Faktor psikologis antara lain: intellegensi, perhatian , minat, bakat, motif, kematangan dan kesiapan.

Sedangkan faktor ekstern digolongkan menjadi tiga faktor yaitu; faktor keluarga, faktor sekolah, dan faktor masyarakat. Faktor keluarga antara lain; cara orang tua mendidik, relasi antara keluarga, suasana rumah tangga, dan keadaan ekonomi keluarga. Faktor sekolah antara lain ; metode mengajar, kurikulum, relasi guru dengan siswa, relasi siswa dengan siswa, disiplin sekolah, pelajaran dan waktu sekolah, standar pelajaran, keadaan gedung, metode belajar, dan tugas rumah. Faktor masyarakat antara lain; kegiatan siswa dalam masyarakat, mass media, teman bergaul, dan bentuk kehidupan masyarakat.Sedangkan yang bersumber dari proses belajar, kemampuan guru dalam mengelola proses pembelajaran sangat menentukan prestasi belajar siswa.

Berdasarkan uraian di atas dapat disimpulkan bahwa pretasi belajar adalah hasil yang dicapai siswa setelah melakukan kegiatan belajar yang berbentuk angka sebagai simbol dari ketuntasan belajar bidang studi IPS. Prestasi belajar yang dimaksud dalam penelitian ini, terbatas pada prestasi belajar IPS pada ranah kognitif saja, sedangkan ranah afektif dan psikomotor tidak dapat dijangkau dalam penelitian ini karena berbagai alasan, misalnya disebabkan oleh kesulitan dalam pembuatan format penetuan kriteria ideal keberhasilan ranah-ranah tersebut, sehingga sulit dalam teknik pengukurannya.

Berdasarkan hasil penelitian yang relevan di atas, maka hipotesis tindakan yang diajukan dalam penelitian ini yaitu; ada pengaruh penggunaan model pembelajaran pemecahan masalah terhadap motivasi dan prestasi belajar IPS siswa kelas VIII MTs. Mu'allimat NW Pancor tahun pembelajaran 2014/2015.

\section{METODE PENELITIAN}

Penelitian yang dilakukan ini tergolong jenis eksprimen. Penelitian eksprimen adalah penelitian yang sistematis, logis, dan teliti di dalam melakukan kontrol terhadap kondisi (Yatim, Rianto: 1996: 28-40). Penelitian ini menggunakan rancangan Quasy ekspriment dalam bentuk Post test only control group design dengan rancangan factorial 1x1. Penentuan kelompok eksperimen dan kelompok kontrol dilakukan secara random sampling. Penelitian yang secara sistematis dan logis menjawab permasalahan hasil manipulasi variabel bebas dengan melakukan penelitian. Desain penelitian ini, 
Pengaruh Model ....- RR. Sri Setyawati M. dan Zidni

subyeknya berupa .kelompok atau rombel yang varalel. Artinya bahwa kelompokkelompok tersebut memiliki kemampuan yang sama. Seluruh rombel memiliki kesempatan yang sama untuk dipilih menjadi kelompok eksprimen dan kelompok kontrol. Masing-masing kelompok dipilih secara random. Kelompok terpilih 1 dijadikan sebagai kelas eksprimen (X) diberikan pembelajaran dengan Model Problem Solving Berbasis Budaya Lokal dan Kelompok kedua disebut kelompok kontrol tidak diberikan perlakuan. Artinya, kelompok ini diberikan pembelajaran menggunakan cara selain yang dilakukan pada kelompok eksprimen. Pengaruh perbedaan perlakuan cara tersebut dilambangkan dengan 01. Penetapan kelompok Eksperimen dan Kontrol dilakukan dengan cara undian Model ini didasari asumsi bahwa kelompok eksprimen dan kelompok kontrol atau pembanding sudah ekuivalen. Desain eksprimen tersebut digambarkan pada tabel di bawah ini.ost tes guna mengetahui pengaruh perlakuan secara ketat dan teliti.

Populasi adalah seluruh data yang akan menjadi perhatian peneliti dalam suatu ruang lingkup waktu yang ditentukan. . Dalam penelitian kuantitatif, populasi diartikan sebagai wilayah generalisasi yang terdiri atas obyek/subyek yang mempunyai kualitas dan karakteristik tertentu yang ditetapkan oleh peneliti untuk dipelajari dan ditarik kesimpulannya(Sugioyono, 2007:49) Populasi bila dilihat dari karakteristiknya dibedakan menjadi dua, yaitu (1) populasi target (actual population), (2) populasi terjangkau (Accesibel population). Kedua jenis populasi tersebut dijelaskan sebagai berikut. Populasi target (actual population) adalah populasi yang dianggap sulit menggeneralisasikannya, Populasi terjangkau (Accesible population) adalah populasi yang dapat digeneralisasikan ( Zuriah, 26). Berdasarkan definisi tersebut, populasi penelitian ini adalah Siswa Kelas VIII MTs.Mu'allimat NW Pancor.

Teknik pengumpulan data merupakan langkah yang penting dalam penelitian. Sebab data-data yang diperoleh selanjutnya akan diolah. Hasil penelitian akan dikatakan bagus apabila dapat dipertanggungjawabkan kebenarannya dan dapat dibuktikan dengan adanya data yang lengkap, autentik dan akurat. Dua cara yang digunakan peneliti dalam mengumpulkan data pada penelitian ini adalah teknik tes dan non tes.

Data yang terkumpul melalui teknik pengumpulan data tidak akan bermakna atau memberikan arti sebelum dilakukan analisis.Teknik analisis data yang digunakan dalam penelitian ini adalah analisis statistik multi variat (MANOVA) dengan bantuan program SPSS 10,0 For Windows. 
Pengaruh Model ....- RR. Sri Setyawati M. dan Zidni

\section{HASIL DAN PEMBAHASAN}

Uji normalitas perlu dilakukan untuk meyakinkan bahwa uji statistik yang digunakan dalam pengujian hipotesis benar-benar dapat dilakukan mengingat uji ini dilakukan agar data dapat digeneralisasikan dan parametrik (data lebih dari dua variabel). Uji normalitas data dilakukan terhadap data motivasi berprestasi siswa yang mengikuti model pembelajaran pemecahan masalah, data motivasi berprestasi yang mengikuti model pembelajaran konvensional, data prestasi belajar IPS siswa yang mengikuti model pembelajaran pemecahan masalah, dan data prestasi belajar IPS siswa yang mengikuti model pembelajaran konvensional pada siswa kelas VIII MTS Mu'allimat NW Pancor .

Normalitas sebaran data diuji dengan teknik Kolmogorov-Smirnov dan ShapiroWilk menggunakan bantuan SPSS 19.00 for windows diperoleh hasil seperti yang tampak pada tabel berikut ini.

\section{Tabel 1: Rekapitulasi Hasil Pengujian Normalitas Sebaran Data dengan Uji Kolmogorov-Smirnov dan Shapiro-Wilk dengan Taraf Signifikansi 5\%}

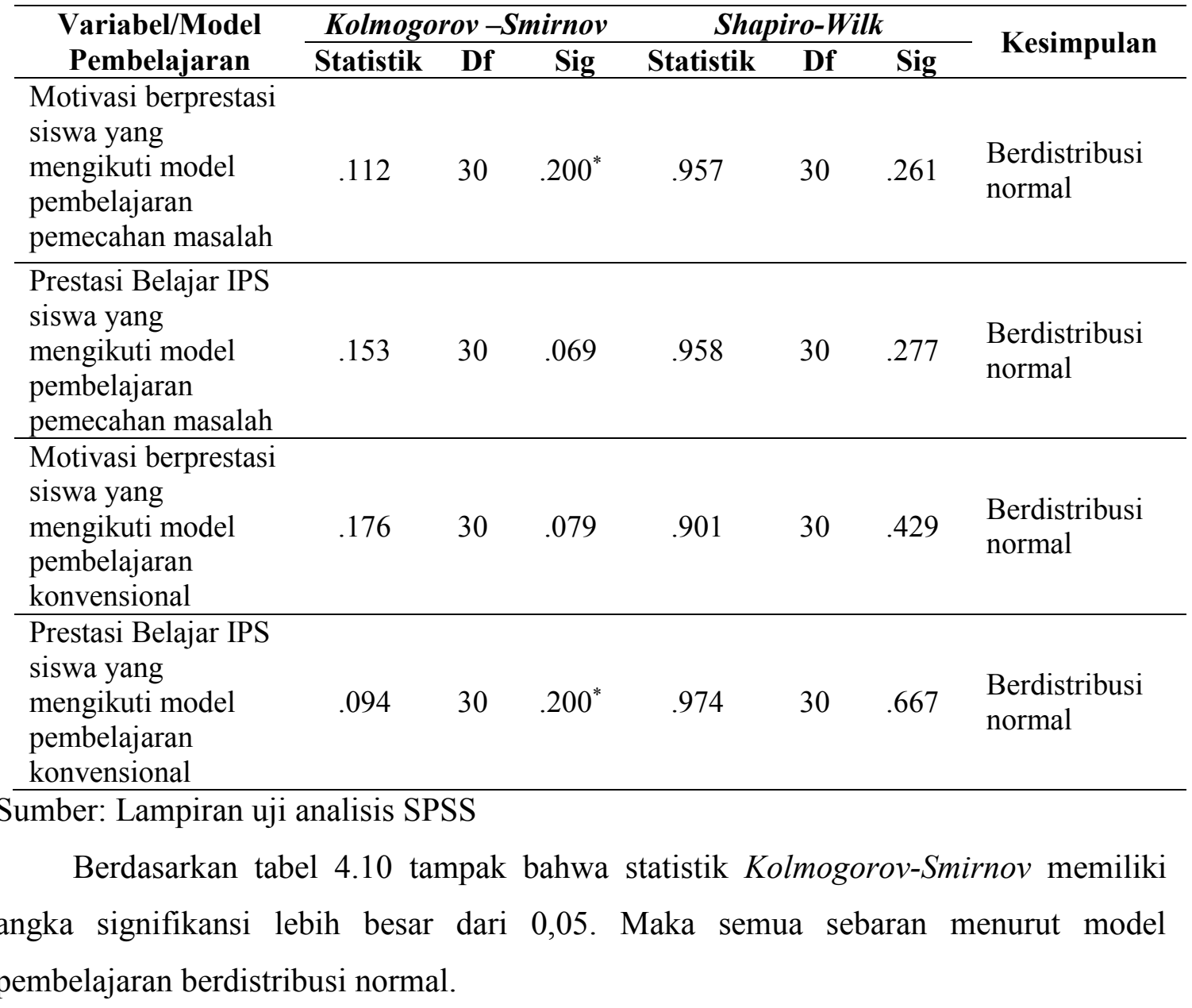


Pengaruh Model ....- RR. Sri Setyawati M. dan Zidni

\section{Uji Homogenitas Varians}

Uji homogenitas varians dilakukan untuk memperlihatkan bahwa dua atau lebih kelompok data sampel berasal dari populasi yang memiliki varians yang sama (Candiasa, 192: 2011). Uji homogenitas dilakukan terhadap kelompok data motivasi berprestasi dan prestasi belajar IPS siswa baik secara bersama-sama maupun secara sendiri-sendiri. Uji homogenitas secara bersama-sama menggunakan uji Box'M menghasilkan angka signifikansi sebesar 0,205 dan secara sendiri-sendiri dengan uji Levene's Test menghasilkan angka signifikansi sebesar 0,121 untuk variabel motivasi berprestasi dan angka signifikansi sebesar 0,211 untuk variabel prestasi belajar IPS. Analisis menggunakan SPSS-19 for windows dengan hasil analisis uji Box' $M$ dan uji Levene's Test dapat ditampilkan sebagai berikut.

Tabel 2: Hasil Analisis Uji Box'M

\begin{tabular}{|c|c|c|}
\hline \multicolumn{3}{|c|}{$\begin{array}{c}\text { Box's Test of Equality of Covariance } \\
\text { Matrices }\end{array}$} \\
\hline \multicolumn{2}{|c|}{ Box's M } & 15.756 \\
\hline \multirow[t]{4}{*}{$\mathrm{F}$} & Approx. & 5.056 \\
\hline & df1 & 3 \\
\hline & $\mathrm{df2}$ & 605520.000 \\
\hline & Sig. & .211 \\
\hline
\end{tabular}

Tabel 3: Hasil Analisis Uji Levene's Test

\begin{tabular}{llllrl}
\hline \multicolumn{5}{c}{ Levene's Test of Equality of Error Variances $^{\text {a }}$} \\
\hline & F & df1 & df2 & Sig. \\
\hline Motivasi Berprestasi & 8.593 & 1 & 58 & .205 \\
\hline Prestasi Belajar IPS & 2.482 & 1 & 58 & .121 \\
\hline
\end{tabular}

Tests the null hypothesis that the error variance of the dependent variable is equal across groups.

a. Design: Intercept $+\mathrm{A}$

Hasil analisis tampak bahwa angka signifikansi yang dihasilkan baik secara bersama-sama maupun sendiri-sendiri lebih besar dari 0,05. Dengan demikian dapat disimpulkan bahwa matrik varian-kovarians terhadap variabel motivasi berprestasi dan prestasi belajar IPS siswa adalah homogen.

\section{Uji Korelasi Antar Variabel Terikat}

Uji korelasi antar variabel terikat dilakukan terhadap data motivasi berprestasi dan prestasi belajar IPS siswa yang belajar dengan model pembelajaran pemecahan masalah dan data motivasi berprestasi dan prestasi belajar IPS siswa yang belajar dengan model 
Pengaruh Model ....- RR. Sri Setyawati M. dan Zidni

pembelajaran konvensional. Uji korelasi dilakukan menggunakan korelasi product moment pada taraf signifikansi 5\% guna menentukan jenis statistik yang digunakan untuk uji hipotesis. Apabila diantar kedua data tidak berkorelasi maka uji hipotesis dilanjutkan dengan Manova, namun bila kedua data berkorelasi maka uji hipotesis dilakukan dengan jenis statistik yang lain. Hasil uji korelasi dengan product moment dapat disajikan pada tabel berikut ini.

Tabel 4: Hasil Uji Product Moment

\begin{tabular}{lccc}
\hline \multicolumn{1}{c}{ Kelompok Sampel } & $\mathbf{r}_{\mathbf{x y}}$ & rtabel & Kesimpulan \\
\hline $\begin{array}{l}\text { Motivasi berprestasi dan prestasi belajar } \\
\text { IPS siswa yang belajar dengan model }\end{array}$ & $-0,01$ & 0,361 & $\begin{array}{c}\text { Tidak } \\
\text { berkorelasi }\end{array}$ \\
pembelajaran pemecahan masalah & & & \\
\hline $\begin{array}{l}\text { Motivasi berprestasi dan prestasi belajar } \\
\text { IPS siswa yang belajar dengan model }\end{array}$ & & & Tidak \\
konvensional & & & berkorelasi \\
\hline
\end{tabular}

Hasil uji korelasi menunjukkan bahwa data motivasi berprestasi dan prestasi belajar IPS siswa yang belajar dengan model pembelajaran pemecahan masalah mendapatkan harga $\mathrm{r}_{\mathrm{y} 1 \mathrm{y} 2}=-0,01$ dan data siswa yang belajar dengan model konvensional mendapatkan harga $r_{\mathrm{y} 1 \mathrm{y} 2}=0,031$ Nilai $r_{\text {hitung }}<r_{\text {tabel }}(0,361)$ pada taraf signifikansi 5\%, maka dapat disimpulkan bahwa data motivasi berprestasi dan prestasi belajar IPS siswa yang mengikuti model pembelajaran pemecahan masalah maupun siswa yang belajar dengan model pembelajaran konvensional tidak berkorelasi. Kedua data dinyatakan tidak berkorelasi, maka pengujian hipotesis dapat dilanjutkan dengan menggunakan Manova.

\section{Uji Hipotesis 1}

\section{Hipotesis}

$\mathrm{H}_{\mathrm{a}}$ : Terdapat perbedaan motivasi berprestasi siswa kelas VIII MTS Mu'allimat NW Pancor antara kelompok siswa yang dibelajarkan model pembelajaran Pemecahan masalah dengan siswa yang dibelajaran dengan model pembelajaran konvensional. $\mathrm{H}_{0}$ : Tidak Terdapat perbedaan motivasi berprestasi siswa kelas VIII MTS Mu'allimat NW Pancor antara kelompok siswa yang dibelajarkan model pembelajaran Pemecahan masalah dengan siswa yang dibelajaran dengan model pembelajaran konvensional. Hasil perhitungan analisis MANOVA dengan menggunakan SPSS 17.00 for windows dapat dilihat pada tabel berikut ini. 
Pengaruh Model ....- RR. Sri Setyawati M. dan Zidni

Tabel 5: Hasil Analisis MANOVA

\begin{tabular}{|c|c|c|c|c|c|c|}
\hline \multicolumn{7}{|c|}{ Tests of Between-Subjects Effects } \\
\hline Source & $\begin{array}{c}\text { Dependent } \\
\text { Variable }\end{array}$ & $\begin{array}{c}\text { Type III Sum } \\
\text { of Squares }\end{array}$ & $\mathrm{df}$ & Mean Square & $\mathrm{F}$ & Sig. \\
\hline \multirow{2}{*}{$\begin{array}{l}\text { Corrected } \\
\text { Model }\end{array}$} & A1Y1A2Y1 & $9779.267^{\mathrm{a}}$ & 1 & 9779.267 & 76.441 & .000 \\
\hline & A1Y2A2Y2 & $3247.233^{b}$ & 1 & 3247.233 & 46.846 & .000 \\
\hline \multirow[t]{2}{*}{ Intercept } & A1Y1A2Y1 & 868806.667 & 1 & 868806.667 & 6791.150 & .000 \\
\hline & A1Y2A2Y2 & 262946.400 & 1 & 262946.400 & 3793.407 & .000 \\
\hline \multirow[t]{2}{*}{ Klmpk } & A1Y1A2Y1 & 9779.267 & 1 & 9779.267 & 76.441 & .000 \\
\hline & A1Y2A2Y2 & 3247.233 & 1 & 3247.233 & 46.846 & .000 \\
\hline \multirow[t]{2}{*}{ Error } & A1Y1A2Y1 & 7420.067 & 58 & 127.932 & & \\
\hline & A1Y2A2Y2 & 4020.367 & 58 & 69.317 & & \\
\hline \multirow[t]{2}{*}{ Total } & A1Y1A2Y1 & 886006.000 & 60 & & & \\
\hline & A1Y2A2Y2 & 270214.000 & 60 & & & \\
\hline \multirow{2}{*}{$\begin{array}{l}\text { Corrected } \\
\text { Total }\end{array}$} & A1Y1A2Y1 & 17199.333 & 59 & & & \\
\hline & A1Y2A2Y2 & 7267.600 & 59 & & & \\
\hline
\end{tabular}

Tabel 6: Hasil Uji Hipotesis Data Motivasi berprestasi

\begin{tabular}{llrccc}
\hline \multicolumn{1}{c}{ Sumber } & Dependent Variabel & df & RJK & F & Sig. \\
\hline $\begin{array}{l}\text { Model } \\
\text { Pembelajaran }\end{array}$ & Motivasi berprestasi & 1 & 9779.267 & 76.441 & .000 \\
\hline
\end{tabular}

Berdasarkan hasil uji analisis multivariate test data motivasi berprestasi siswa yang dibelajarkan dengan model pembelajaran pemecahan masalah dan model pembelajaran konvensional menghasilkan harga $\mathrm{F}$ sebesar 76,441, df $=1$, dan Sig $=$ 0,000. Ini berarti signifikansi lebih kecil dari 0,05. Dengan demikian hipotesis nol $\left(\mathrm{H}_{0}\right)$ ditolak dan hipotesis alternatif $\left(\mathrm{H}_{\mathrm{a}}\right)$ yang menyatakan terdapat Terdapat perbedaan motivasi berprestasi siswa kelas VIII MTS Mu'allimat NW Pancor antara kelompok siswa yang dibelajarkan model pembelajaran Pemecahan masalah dengan siswa yang dibelajaran dengan model pembelajaran konvensional, diterima. Hasil analisis multivariate hipotesis 1 .

\section{Uji Hipotesis 2}

\section{Hipotesis}

Ha: Terdapat perbedaan prestasi belajar IPS antara siswa yang mengikuti pembelajaran model pemecahan masalah dengan model pembelajaran konvensional pada mata pelajaran IPS kelas VIII MTS Mu'allimat NW Pancor. $\mathrm{H}_{0}$ : Tidak terdapat 
Pengaruh Model ....- RR. Sri Setyawati M. dan Zidni

perbedaan prestasi belajar IPS antara siswa yang mengikuti pembelajaran model pembelajaran pemecahan masalah dengan model pembelajaran konvensional pada mata pelajaran IPS kelas VIII MTS Mu'allimat NW Pancor Hasil analisis multivariate test data prestasi belajar IPS siswa yang mengikuti model Pemebelajaran pemecahan masalah dengan model pembelajaran konvensional dengan berbantuan SPSS 19.0 for windows didapatkan hasil seperti pada tabel berikut ini.

Tabel 7: Hasil Uji Hipotesis Data Prestasi Belajar IPS Siswa

\begin{tabular}{llllll}
\hline \multicolumn{1}{c}{ Sumber } & \multicolumn{1}{c}{$\begin{array}{c}\text { Dependent } \\
\text { Variabel }\end{array}$} & Df & RJK & F & Sig. \\
\hline $\begin{array}{l}\text { Model } \\
\text { Pembelajaran }\end{array}$ & $\begin{array}{l}\text { Prestasi Belajar } \\
\text { IPS Siswa }\end{array}$ & 1 & 3247.233 & 46.846 & .001 \\
\hline
\end{tabular}

Hasil analisis data prestasi belajar IPS siswa yang mengikuti pembelajaran model pembelajaran pemecahan masalah dengan pembelajaran konvensional diperoleh nilai $\mathrm{F}$ sebesar 46,846 , df $=1$, dan sig $=0,001$. Ini berarti signifikansi lebih kecil dari 0,05. Dengan demikian hipotesis nol $\left(\mathrm{H}_{0}\right)$ ditolak dan hipotesis alternatif $\left(\mathrm{H}_{\mathrm{a}}\right)$ yang menyatakan terdapat perbedaan prestasi belajar IPS antara siswa yang mengikuti pembelajaran model pembelajaran pemecahan masalah dengan model pembelajaran konvensional pada mata pelajaran IPS kelas VIII MTS Mu'allimat NW Pancor, diterima. Hasil analisis mutivariat hipotesis 2.

\section{Uji Hipotesis 3}

\section{Hipotesis}

Ha: Terdapat perbedaan motivasi berprestasi dan prestasi belajar IPS secara simultan antara siswa yang mengikuti pembelajaran model Pembelajaran pemecahan masalah dengan model pembelajaran konvensional pada mata pelajaran IPS kelas VIII MTS Mu'allimat NW Pancor. $\mathrm{H}_{0}$ : Tidak terdapat perbedaan motivasi berprestasi dan prestasi belajar IPS secara simultan antara siswa yang mengikuti pembelajaran model Pembelajaran pemecahan masalah dengan model pembelajaran konvensional pada mata pelajaran IPS kelas VIII MTS Mu'allimat NW Pancor.Selanjutnya untuk mengetahui perbedaan motivasi berprestasi dan prestasi belajar IPS siswa yang mengikuti kedua model pembelajaran tersebut, dilakukan analisis dengan menggunakan Manova (Multivariate Analysis of Variance) dengan berbatuan SPSS 19.0 For Windows. Kriteria pengujian adalah jika harga F untuk Pillae Trace, Wilk Lambda, Hotelling's Trace, Roy's Largest Root lebih kecil dari 0,05. Berarti semua nilai Pillae Trace, Wilk Lambda, Hotelling's Trace, Roy's Largest Root signifikan. Maka, hipotesis nol $\left(\mathrm{H}_{0}\right)$ ditolak dan 
Pengaruh Model ....- RR. Sri Setyawati M. dan Zidni

hipotesis alternatif (Ha) berarti diterima. Ringkasan hasil analisis menggunakan Manova dapat disajikan pada tabel berikut.

\section{Tabel 8: Ringkasan Hasil Analisis Intensitas Keterlibatan Motivasi Berprestasi dan Prestasi Belajar IPS Siswa dengan Manova}

\begin{tabular}{clll}
\hline Effect & \multicolumn{1}{c}{ Statistik } & \multicolumn{1}{c}{ F } & P \\
\hline Model & Pillae Trace & 64.269 & .000 \\
\cline { 2 - 4 } Pembelajaran & Wilk Lambda & 64.269 & .000 \\
\cline { 2 - 4 } & Hotelling's Trace & 64.269 & .000 \\
\cline { 2 - 4 } & $\begin{array}{l}\text { Roy's Largest } \\
\text { Root }\end{array}$ & 64.269 & .000 \\
\hline
\end{tabular}

Berdasarkan hasil analisis pada tabel tersebut, tampak bahwa harga p lebih kecil dari 0,05 pada nilai Pillae Trace, Wilk Lambda, Hotelling's Trace, Roy's Largest Root. Ini berarti hipotesis nol $\left(\mathrm{H}_{0}\right)$ ditolak dan hipotesis alternative $\left(\mathrm{H}_{\mathrm{a}}\right)$ yang menyatakan terdapat perbedaan motivasi berprestasi dan prestasi belajar IPS secara simultan antara siswa yang mengikuti pembelajaran model Pembelajaran pemecahan masalah dengan model pembelajaran konvensional pada mata pelajaran IPS kelas VIII MTS Malimat NW Pancor, diterima.

Hasil uji hipotesis dalam penelitian ini terbukti bahwa: Pertama, motivasi berprestasi siswa yang mengikuti model pembelajaran pemecahan masalah (kelompok eksperimen) hasilnya lebih baik daripada motivasi berprestasi siswa yang mengikuti model pembelajaran konvensional (kelompok kontrol). Berdasarkan data hasil analisis multivariat dengan bantuan SPSS 19 for windows diperoleh nilai $\mathrm{F}$ sebesar 76,441, df = 1 , dan Sig $=0,000$. Ini berarti signifikansi lebih kecil dari 0,05 dapat ditarik simpulan bahwa terdapat perbedaan yang signifikan motivasi berprestasi antara siswa yang belajar dengan model pembe;lajaran pemecahan masalah (kelompok eksperimen) dengan siswa yang mengikuti model pembelajaran yang mengikuti mode pembelajaran konvensional (kelompok kontrol).

Berdasarkan data hasil analisis tersebut, secara teoritis dapat dikatakan bahwa penggunaan model pemecahan masalah dan efektif untuk meningkatkan motivasi berprestasi siswa dalam proses pembelajaran. Model ini memberikan ruang yang cukup kepada siswa untuk memahami bahwa lingkungan mereka dipenuhi dengan berbagai macam budaya, tradisi, dan kebiasaan yang harus dihargai guna mempererat rasa memiliki sebagai bagian dari kulturalisasi bangsa, peka terhadap masalah-masalah sosial yang terjadi dilingkungannya, serta belajar membuat keputusan yang tepat dan bijaksana berkaitan dengan masalah sosial-budaya yang dihadapinya. Selain itu melalui 
Pengaruh Model ....- RR. Sri Setyawati M. dan Zidni

model pembelajaran ini siswa lebih termotivasi untuk berkreativitas, berprakarsa, bereksplorasi, dan mengkonstruksi pengetahuan yang didengar, bekerja sama dengan teman untuk mendiskusikan tentang solusi dari suatu masalah serta mempresentasikan hasil temuannya.

\section{DAFTAR PUSTAKA}

Listiyani, Dwi Ari. 2009. Sejarah Untuk SMA/MA Kelas XI Program IPS. Jakarta: Pusat Pembukuan Departemen Pendidikan Nasional.

Suharsimi. 2006. Prosedur Penelitian Suatu Pendekatan Praktik. Jakarta: PT Rineka Cipta.

Asmawi, Zaenal. 2001. Alternatif Assesmen. Jakarta: Depdiknas.

Hassan, Hamid. 1996. Pendidikan Ilmu-ilmu Sosial, Buku I. Bandung: Jurusan Sejarah FP IPS IKIP Bandung.

Koyan, I Wayan. 2011. Asesmen dalam Pendidikan. Singaraja: Universitas Pendidikan Ganesha Press.

Sanjaya, Wima. 2008. Strategi Pembelajaran Berorientasi Standar Proses Pendidikan. Jakarta: Prenada Media.

Sapriya. 2009. Pendidikan IPS, Konsep dan Pembelajaran. Bandung: Remaja Rosda Karya.

Sardiman, dkk. 2012. Pembelajaran IPS Terpadu Untuk Kelas VIII SMP dan MTS, Solo: PT Tiga Serangkai.

Sardjiyo. 2005. Pembelajaran Berbasis Budaya, Model Inovasi Pembelajaran dan Implementasi Kurikulum Berbasis Kompetensi. Jurnal Pendidikan, Volume 6 Nomor 2, September 2005.

Sindhunata. 2006. Menggagas Para Digma Baru Pendidikan. Yogyakarta: Kanisius.

Syah, Muhibbin. 2008. Psikologi Belajar. Jakarta: Raja Grapindo Persada.

Sukmadinata, Nana Syaodih. 2002. Pengembangan Kurikulum, Teori Dan Praktek. Bandung: PT Karya Rosdakarya. 